\title{
Group Agents and Moral Status: What Can We Owe to Organizations?
}

\author{
Adam Lovett ${ }^{1}$ (D) and Stefan Riedener ${ }^{2 *}$ (1) \\ ${ }^{1}$ Department of Philosophy, New York University, USA, and ${ }^{2}$ Department of Philosophy, University of Zurich, Switzerland \\ ${ }^{\star}$ Corresponding author. Email: stefan.riedener@philos.uzh.ch
}

\begin{abstract}
Organizations have neither a right to vote nor a right to life. But we can owe them to keep our promises or show them gratitude. So we owe some things to organizations, but not everything we owe to people. What explains this? Individualistic views explain it just in terms of features of organizations' individual members. Collectivistic views explain it just in terms of features of those organizations. Neither view works. Instead, we need to synthesize these approaches. Some individual interests are distinctively collective. Individuals have an interest in participating in successful collective action. This explains organizations' apparently fragmented moral status.
\end{abstract}

Keywords: Group agents; organizations; interest theory of rights; moral status; political obligations.

\section{Introduction}

Prima facie, organizations have a peculiar, fragmented moral status. We can owe them some things. But we can't owe them everything we can owe to people. Consider:

Right to Vote: You're an electoral commissioner responsible for enfranchising the disenfranchised. One day, an odd complaint from Goldman Sachs lands on your desk. "In 1920, the vote for women was secured. In the sixties, the Voting Rights Act was passed. But we have not yet breached the final frontier of political equality!" You continue reading with interest. "Organizations throughout the land-corporations, colleges, clubs-are still denied suffrage. But we too have a moral right to set the laws we live under. Goldman demands a say about the general will!"

The bank seems misguided. We owe it to our fellow citizens to grant them the power to vote. Our fellow citizens have a right to set the laws they live under. But organizations do not. In this respect, organizations are not at all like people.

Similarly, consider:

Right to Life: You're Chief Justice Edward D. White. The issue of the day is whether to break up Standard Oil. The trust busters have put forward a good argument. They've told you about the firm's ruthless history. They've told you how it bankrupted its competitors. They've told you how it won a stranglehold on oil production and then jacked up oil prices. But, in closing arguments, the representative for Standard Oil emits a surprising and impassioned plea. "I don't deny my client has sharp elbows" he says. "But we would never end the existence of a human being merely due to their business acumen. Human beings have a moral right to life."

\footnotetext{
(c) The Author(s) 2021. Published by Canadian Journal of Philosophy. This is an Open Access article, distributed under the terms of the Creative Commons Attribution licence (http://creativecommons.org/licenses/by/4.0/), which permits unrestricted re-use, distribution, and reproduction in any medium, provided the original work is properly cited.
} 
You listen bemusedly. "And so we should not end the existence of Standard Oil. It has rights like any flesh-and-blood person."

The lawyer also seems misguided. We owe it to human beings not to end their existence. Human beings have an especially weighty right to life. But organizations do not. Perhaps we should not destroy them on a whim. But their inviolability is no momentous issue. In this respect too, organizations are not at all like people.

But there are other respects in which organizations seem just like people. Consider:

Promissory Claims: You just signed a contract with the University of Oxford. You promised that you'll set up a new graduate program by October. But you feel like it's time for a holiday. By late September, you haven't lifted a finger for the program. The university gets panned by the press. It is a complete embarrassment. How could such an august organization be taken in by a loafer like you? Soon enough, you receive a haranguing phone call from the vice chancellor: "We had a claim on you. Through your perfidious breach of your promise, you wronged our beloved university."

The vice chancellor seems right. It's not just people to whom we have promissory obligations. We can make promises to organizations. When we break them, we seem to wrong the organization. In this respect, organizations are just like people. Both seem to be the bearers of promissory claims.

Finally, consider:

Claims of Gratitude: You're a successful lawyer. You're living the American dream. White picket fence, two kids, nosy neighbors, you name it-you've got it. But your life was not always so charmed. Your parents died in a terrible car accident in your early years. Fortunately, Galveston Orphans Home took you in. It gave you as good a childhood as possible in the circumstances. In fact, it gave you a wonderful childhood. Its ministrations are responsible for the success you've made of your life. But now the orphanage is in trouble. Its investments went sour, one thing lead to another, and it needs cash quick. So you receive a letter from it: "We know this is a little forward. But we ask you to consider helping the orphanage in these difficult times. We appeal to your sense of gratitude."

The letter seems warranted. It's not just people to whom we can owe debts of gratitude. When organizations have helped us, we seem to owe them debts of gratitude too. In this respect too, organizations are just like people. Both seem to be the bearers of claims on our gratitude.

So, prima facie, organizations have a peculiar, fragmented moral status. They can have certain claims on us, but not others. We seem to owe it to them to keep our promises. We seem to owe them debts of gratitude. But they don't have the rights to life people have. And they don't have the full gamut of political rights. That seems mysterious. Why would anything (seem to) have such an eclectic collection of claims on us? This puzzle is the topic of this paper.

Let's get clearer on the puzzle. When we say that something has full moral status, we mean it can make the full range of moral claims on us. Any moral obligation we can have to a flesh-and-blood person we can have to that thing. When we say that something has a fragmented moral status, we mean it can make some, but only some, kinds of moral claims on us. Thus, we can have some, but only some, kinds of moral obligations toward it. These obligations don't merely concern the thing. You can have obligations concerning your hat, but your hat doesn't have moral status. They're obligations to the thing. They're directed obligations. We don't have an account of what such obligations are. But, intuitively, there are directed obligations. Sometimes we don't just have obligations tout court. We owe things to particular moral subjects. ${ }^{1}$

\footnotetext{
${ }^{1}$ See e.g., Darwall (2006), Owens (2012, chap. 2), or Wallace (2019) for prominent elaborations of this idea.
} 
When we say that something is an organization, we mean that it is a group agent. A group agent is an agent made up of other agents. Companies, states, clubs, and charities can all be group agents. They're agents in that they have beliefs, desires, and intentions and those mental states are rationally integrated. When they want something, they'll intend to do what they think is a necessary means to get what they want. When they believe they ought to do something, they will form an intention to do it. Several authors have defended this way of thinking about organizations (see e.g., List and Pettit 2011; Huebner 2014; Tollefsen 2015; Epstein 2015). It is now common. So we'll presuppose that organizations are group agents for the rest of the paper. The puzzle is why such organizations appear to have a fragmented moral status.

A good solution to this puzzle needn't imply that organizations really do have fragmented moral status. Appearances, after all, can be misleading. But it must explain why organizations appear to have such an eclectic collection of claims on us. Two approaches to this seem natural: individualistic and collectivistic. Individualistic views explain these obligations entirely in terms of individualistic notions. These notions invoke only the features of flesh-and-blood individuals. They make no reference to organizations. We explore this approach in section 2. We think it fails. It doesn't explain how our obligations to organizations seem to work. Collectivistic views explain these obligations entirely in terms of collective notions. These notions invoke only the features of organizations. They make no reference to flesh-and-blood individuals. We explore this approach in section 3. We think it also fails. No plausible theory of moral status can underpin such a view. Thus, in section 4 , we outline and defend a synthesis of these solutions. We call this the Group Interest View. This view says that some individual interests are distinctively collective. As individuals, we have distinctive interests in participation in successful group agency. To properly respect this interest, we must treat organizations as if they had a peculiar, fragmented moral status. But in the final analysis, the moral status of organizations is merely apparent: they themselves can make no claims on us at all. We must keep our promises to them and show them gratitude to respect the claims of their members. We think this is the best solution to the puzzle. In section 5, we end by discussing the implications of the Group Interest View for the apex organization: the state. The view undermines the political obligations of the subjects of autocracies but leaves untouched those of the citizens of democracies.

Our discussion contributes to several fields. First, it contributes to our understanding of the place of group agents in our moral life. It has been much discussed whether group agents are moral subjects - whether they are morally responsible or themselves have obligations (see e.g., List and Pettit 2011; Hess 2014). But it has been much less discussed whether group agents are moral objects - whether they can have claims or whether we can owe them things. Our discussion illuminates this issue. ${ }^{2}$ Second, our discussion matters to theories of moral status. We show that organizations provide an important test case for such theories; such theories better deal adequately with the case of organizations. Third, our discussion matters to theories of welfare. We show that organizations provide an important test case for these theories too. And, more substantively, we propose that welfare is in part constituted by group activity. Our puzzle thus implicates important parts of contemporary ethics.

\footnotetext{
${ }^{2}$ This issue hasn't been wholly overlooked. Hess (2013) distinguishes between these two issues and suggests that corporations, at least, can make no moral claims. Wringe (2014) argues that organizations can't have a claim against being treated as mere means. Raz $(1984,204)$ thinks that organizations can make moral claims but says little about why. List (2016, 315) addresses the issue very briefly. Briggs (2012) raises the issue but doesn't address it. Hedahl (2017) addresses it more extensively. List and Pettit (2011) explore whether and why we can have conventional (e.g., legal) obligations toward organizations. Note that we're not addressing the rights of social groups—races, nationalities, genders (see e.g., Appiah, 2011); we're interested in the rights of group agents.
} 


\section{Individualism}

Let's define an individualistic notion as a notion which makes no reference to organizations. It makes reference to flesh-and-blood individuals alone. Individualistic views attempt to explain the obligations in our opening cases purely by employing individualistic notions. We'll focus on one view of this kind. We'll call it Individualism. This view says that when it seems we owe something to an organization, we really just owe that very thing to one or more of its members. ${ }^{3}$ For example, suppose you had a good childhood in the Galveston Orphans Home. Well, then there must be some members of the orphanage who helped you. So it's each of these members to whom you'll owe a debt of gratitude. Similarly, suppose you signed a contract with Oxford to set up a graduate program. Then there must be a member of the university with whom you signed that contract. So it's really just that member of the university to whom you have a promissory obligation. In neither case do you have an obligation in virtue of any feature of organizations. Thus, according to Individualism, our intuitions about organizations are misguided. But they're misguided in an understandable way. We're confusing an obligation to one or more members of an organization for that obligation to the organization itself.

This view is neat and simple. But, unfortunately, it fails to explain how our obligations to organizations seem to work. We'll note three problems for the view. The first problem concerns how such obligations are or aren't transferred. This problem arises from the fact that organizations change their members. The people who made up Galveston Orphans Home when it benefited you might no longer make it up today. Those who made up Oxford when you signed your contract might have all fled the Oxford coop. In such cases, intuitively, many of our obligations stick with the organization. Even if their members have changed, you still owe gratitude to the orphanage. You still owe the fulfilment of your contract to the university. But, according to Individualism, all our obligations would stick with the original people. You have no reason to give anything to the orphanage; you have reason to help the social workers or administrators whom the orphanage employed. It's they who benefited you. Similarly, you owe nothing to the university itself; you only owe something to its old members. It's them to whom you have promised. In short, when organizations change their members, Individualism can't explain why claims stick with the organization rather than move with the (former) members.

The second problem concerns how the claims corresponding to these obligations are assumed. This problem arises from the fact that the members of organizations often don't assume claims that match those obligations. Take gratitude. Plausibly, beneficence only generates a debt of gratitude when it goes beyond the call of duty. If someone was obligated to benefit you, you don't owe them gratitude. ${ }^{4}$ Suppose a horse you've bet on wins a race. It might be intelligible for you to thank the jockey. But the jockey has no claim on your gratitude. They were just doing their job. They were obliged to ride the horse hard. But members of organizations are often in the same position. The teachers and administrators of the orphanage might have been just doing their jobs. Their benefiting you may also have been well within the call of duty. So no member need to have done what's needed to assume a claim of gratitude. Yet you would still seem to owe the organization a

\footnotetext{
${ }^{3}$ There are other possible individualistic views. One alternative says that when we owe something to an organization, it's really because of our own interests. Perhaps, for instance, we can have promissory obligations to an organization due to our interest in being able to bind ourselves. But this view strikes us as implausible. If it was our interest in self-binding that generated the obligation, then it would seem that it would be a duty that we owed to ourselves. Yet when you have a promissory obligation to an organization, the duty is not owed to yourself. It seems owed to the organization. So, in the text, we focus on views that invoke the members of organizations. Note that the distinction between individualistic and collectivistic views is not one with a preexisting life in the literature. It is one that we have invented. We have done this simply because the puzzle we are discussing is a novel one, and, so, there are no existing attempts to solve it.

${ }^{4}$ This is the standard view in the literature; see e.g., Walker $(1980,48)$, Heyd $(1982,140)$, Weiss $(1985,493)$, or Macnamara (2019). For people who deny this view, see e.g., Simmons $(1979,179-81)$ or McConnell $(1993,16)$.
} 
debt of gratitude. ${ }^{5}$ A similar point goes for promises. Promises need uptake. Someone only has a promissory claim on you if they (or their agent) accepted a promise from you to them. When I accept your promise on behalf of my sister, you don't owe me anything at all. You owe my sister what you promised. But there might be no member of the organization who's accepted a promise to them. They might all think of themselves as having accepted a promise to the organization. So no member need to have done what's needed to assume a promissory claim. But you would still seem to be obliged to keep your promise. In short, Individualism can't explain why the organization seems to have certain claims on you even when none of its members have assumed such claims.

The third problem concerns how the obligations are discharged. It concerns how you can move from owing something to an organization to owing nothing to that organization. This problem has two aspects. On the one hand, there's an issue of how we can fulfil these obligations. That means how we can successfully do what we're obliged to do. Take debts of gratitude. We can fulfil such debts in many ways. We can avoid harming, and perhaps benefit, the person to whom we're grateful. But if you owe this to the people that make up the orphanage, you can do this by benefiting them. You can buy them all flowers or help their kids get to college. Plausibly, you should often do such things. But intuitively, when you benefited from an organization, that isn't all you ought to do. You also ought to benefit the organization itself. On the other hand, there's an issue of how we ought to compensate organizations for failures to fulfil our obligations. Take promissory obligations. When you fail to keep a promise, you have not discharged your promissory obligations. You should compensate the promisee for your failure. But suppose you owe your promise to the members of the University of Oxford. Then you should discharge this duty by making those members whole again. You could give them money individually, say, or stock up their private wine collections. But intuitively, that isn't all you ought to do. You should compensate the university itself. In short, Individualism does not capture how we can discharge the obligations we seem to owe to organizations.

Individualism is thus unsatisfactory. It fails to explain why many of your obligations seem to stick with the organization when its members change. It fails to explain why the organization seems to have a claim on you even when the members have not assumed such a claim. And it fails to explain why you only seem able to discharge your obligations to organizations in certain ways. So, perhaps, to solve our puzzle, we do need to refer to the features of organizations. Perhaps these features explain their apparent moral status.

\section{Collectivism}

Let's define a collectivistic notion as a notion which makes no reference to flesh-and-blood individuals. It makes reference to group agents and their features alone. Collectivism attempts to explain the obligations in our cases purely by employing collectivistic notions. In particular, Collectivism says that the features of organizations, together with the right general theory of moral status, explain why organizations have exactly the moral status they seem to have. We'll consider two families of Collectivist view. These are distinguished by what theory of moral status they adopt. First, we'll consider views which adopt a single-source theory of moral status. These theories say that there's some single property, $F$, the possession of which alone grounds the ability to make every

\footnotetext{
${ }^{5}$ One might think that this line of thought undermines the claim that you genuinely owe gratitude to the orphanage itself. After all, one might think, orphanages are obligated to look after orphans. Doing so is not beyond the call of duty for them. Perhaps, but we doubt that orphanages are obligated to look after specific orphans. Their capacity is limited, so if the orphanage had taken in a different orphan than you, it would not have been doing anything wrong. Thus, we doubt this argument alone defeats the claim that people can owe gratitude to organizations. Having said that, our ultimate view (section 4) is that you don't owe genuine duties of gratitude to organizations. So, even were this argument sound, it would cohere well with our considered position.
} 
kind of moral claim. ${ }^{6}$ Second, we'll consider views which adopt a dual-source theory of moral status. These theories say that the possession of one property, $G$, grounds the ability to make some claims and the possession of another property, $H$, grounds the ability to make distinct claims. Both families of views aim to vindicate our intuitions about organizations. Both families say that organizations have exactly the peculiar, fragmented moral status they seem to have. But we think each family is unhappy, albeit in its own way. So we doubt that Collectivism provides a good solution to our puzzle.

We start with the first family. These views say that a single property grounds moral status and that organizations' possession of this property explains their fragmented moral status. We think that any such view faces a general problem. Single-source theories tend to grant organizations full moral status or none at all. To see this, we'll look at the two such theories most prominent in the Western philosophical tradition. The first says that agency is the source of all moral status. There are several ways to fill this out. For instance, perhaps rational agency is an end in itself that demands our respect. By breaking our promises to rational agents or by showing them ingratitude, we fail to respect their rational agency. Perhaps that's why these things are wrong. Alternatively, perhaps what we owe to each other is set by the rules we'd agree to in some hypothetical position. Perhaps rational agency is the price of admission to that position. Only rational agents get a say in bargaining over moral norms. And perhaps such agents would reject norms on which we may break our promises to them or not show them gratitude. On either theory, rational agency is the fount of all directed obligations. One type of Collectivist view says that these theories can explain the fragmented moral status of organizations.

Such views aren't hopeless. After all, consider animals. Animals, arguably, have a fragmented moral status. You owe it to your dog not to kill it. But you don't owe your dog the vote. Agential single-source theories can tell a story about this. Killing your dog impairs its agency. But it can't vote. So disenfranchising it doesn't impair its agency. ${ }^{7}$ Thus, such theories can explain the fragmented moral status of some entities. And so perhaps they can explain that of organizations. But we doubt it. These theories might explain why we'd wrong an organization by breaking our promises to it or showing it ingratitude. Organizations are rational agents. Perhaps such behavior would impair their agency. Or perhaps they would reject norms that allowed us to treat them in this way. But such theories also imply that organizations have a right to the vote and a weighty right to life. After all, organizations are rational agents. Disenfranchising them and dissolving them impairs this agency. Keeping the vote from Goldman limits its political participation. Breaking up Standard Oil snuffs out its agency altogether. On the view under consideration, they have weighty claims against such impairments. Thus, they should have voting rights and a weighty right to life. So agential single-source theories give organizations all the claims that flesh-and-blood people have.

Let's turn to a second single-source theory. This theory says that welfare is the source of all moral status. There are, again, several ways to fill this out. For instance, perhaps if something harms you, we owe it to you not to do it. We owe it to people not to reduce their welfare. This aptly explains why you have full moral status. Ending your existence, disenfranchising you, breaking promises to you, and not showing you gratitude all harm you. So you have a claim on us not to do these things. Alternatively, perhaps what matters is not whether an action actually harms you. Perhaps it is whether it tends to harm you. On this view, if an action is of a kind which tends to harm people, we owe it to each subject not to inflict it on them. So it matters not whether every promise-breaking or disenfranchisement damages welfare. What matters is that such acts tend to damage welfare. Another type of Collectivism says that these theories can explain the fragmented moral status of organizations.

\footnotetext{
${ }^{6}$ The notion of ground in play is full ground. See Fine $(2012,50)$.

${ }^{7}$ For a story a little like this, see Thomas (2016).
} 
This again seems doubtful. The exact problem depends on whether organizations can have welfare. Suppose that they can have welfare. This could be because welfare consists in the satisfaction of desires and organizations can have their desires satisfied. If so, we could explain why you seem to wrong an organization when you break your promises to it or show it ingratitude. Doing so diminishes its welfare. But then you'll also wrong organizations by denying them suffrage and ending their existence. Both seem likely to frustrate their desires, and so to diminish their welfare. So, in this case, organizations will have all the claims flesh-and-blood people have. Alternatively, suppose organizations cannot have welfare. This could be because having welfare requires phenomenal consciousness and organizations lack such consciousness. If so, we could explain why we don't wrong organizations when we break them up or deny them suffrage. Since organizations can't have a welfare, they don't have claims against being broken up or denied suffrage. But organizations will lack all other claims too. For if they can't have welfare, breaking promises to them or showing them ingratitude cannot impair their welfare. Thus, in this case, organizations will have none of the claims flesh-and-blood people have.

So neither single-source theory is of much use to Collectivism. They either give organizations full moral status or none at all. Thus, we turn to our second family of Collectivist views. These rely on dual-source theories. On such theories, there are two ultimate sources of moral status. One property grounds political rights and the right to life. Another property grounds the ability to make promissory claims and claims of gratitude. The most natural such theory invokes welfare and agency. To aid Collectivism, it must say that welfare alone grounds rights to life and political rights whilst agency alone grounds claims to promise-keeping and gratitude. Collectivists can then claim that organizations lack welfare but have agency. They thus lack the right to life and political rights but can make promissory claims and claims of gratitude. So this theory could vindicate our intuitions about the moral status of organizations. If it is true, then organizations might have exactly the fragmented status that they seem to have.

Unfortunately, this theory is not plausible. For suppose our having agency grounds our ability to make promissory claims and claims of gratitude. Perhaps promise-breaking and ingratitude impair our ability to execute our rational choices. They thus disrespect our agency. But then, surely, ending our existence or denying us the vote also disrespect our agency. Ending our existence impairs this ability at least as much as breaking promises to us does. ${ }^{8}$ Denying us the vote impairs it at least as much as does showing us ingratitude. So agency should ground these political rights and the right to life too. Rational agents should have these rights. Yet the theory in question denies this. It says that welfare alone grounds such rights. And it has to say that for it to aid Collectivism. Otherwise, organizations will have the rights that intuition denies them. They will have the right to life and to the vote. Thus, this theory seems ad hoc. It seems to have no principled reason for denying that agency grounds these rights. That makes it implausible.

We suspect that this point generalizes. Collectivism needs a dual-source theory on which one property, and that property alone, grounds claims to gratitude and promise-keeping. But another property, and that alone, grounds claims to political rights and the right to life. It can then hold that organizations have the first property but lack the second. But we suspect that any such theory will be implausible. Now we can't fully substantiate this suspicion without going through every possible dual-source theory. This is a Herculean task and, unfortunately, the blood of Greek deity does not course through our veins. But there is a general reason to hold it. If a property grounds one type of claim, there must be no in-principle barrier to it grounding claims. Thus, it seems plausible that it can ground other types of claims. And our suspicion is validated by the most natural dual-source

\footnotetext{
${ }^{8}$ One might deny that this is true of organizations on the grounds that ending an organization's existence is never to treat it as a mere means. But that seems false: if a private equity firm dissolves a business to make money selling off its component parts, it is surely treating the business as a mere means. It is not valuing the business in itself, but rather treating it as a means to make money. For more on this, see Wringe (2014).
} 
theory: the one which invokes welfare and agency. So we doubt this second family of Collectivist views helps solve the puzzle. Thus, Collectivism seems in as bad a position as Individualism. Neither can explain the apparent moral status of organizations.

\section{The Group Interest View}

\section{4.a. Our proposal}

We've seen that our puzzle can be easily solved neither by employing purely individualistic notions nor by employing purely collectivistic notions. But we think it can be solved nonetheless. The key is synthesis. We think that individuals have distinctive interests in collective actions. In particular, individuals have an interest in the participation in successful instances of group agency. But interests generally give rise to claims. And this distinctive interest gives rise to the claims by the members of organizations which match what we appear to owe to organizations. We'll call this the Group Interest View. From Collectivism, it borrows a focus on the distinctive features of organizations. From Individualism, it borrows a focus on the moral features of the individuals in those organizations. On this view, to be clear, the apparent moral status of organizations is merely apparent: we don't really owe organizations anything. But treating organizations as if they had a fragmented moral status respects the core interests of their members. Thus, the nature of the obligations in our opening cases is unveiled. They're obligations grounded in the distinctive interest in collective action.

Let's spell out the proposal in more depth. It is based on an interest theory of moral claims (see e.g., MacCormick 1977; Raz 1984; 1986; Kramer 2001). As we'll understand it, this theory says:

Interest-Theory: $A$ has a claim against $B$ that $B \varphi$ if and only if $A$ has a legitimate interest in $B$ 's $\varphi$-ing that's weighty enough to hold $B$ under a duty to $\varphi$.

We'll start by clarifying terms. First, what's an 'interest'? We'll say that $A$ has an interest in $B$ 's $\varphi$-ing if and only if $B$ 's $\varphi$-ing would improve $A$ 's welfare. It would, in other words, make $A$ 's life better for $A$, or increase $A$ 's well-being. Second clarification: when is an interest 'legitimate'? An interest is legitimate only when your having it doesn't violate an independent constraint. You might be a sadist. You might have a strong desire that others suffer. But you shouldn't have such a desire. You should wish peace and love to all. So your interest in other people suffering is not a legitimate interest. Third, when is $A$ 's legitimate interest in $B$ 's $\varphi$-ing 'weighty enough to hold $B$ under a duty to $\varphi$ '? When it is much weightier than the legitimate, countervailing interests of others. You might have a legitimate interest in someone's not applying for a job. But they'll have a legitimate interest in applying. Your interest is rarely much weightier than their interest. So this rarely gives you a claim that they do not apply. Your interests give you claims only when they greatly outweigh other people's legitimate interests.

We now make an important assumption. Organizations do not have welfare. They don't have lives which can go better or worse in a morally significant way. We're inclined to found this assumption on two further thoughts. First, organizations are not phenomenally conscious. There is nothing it is like to be Standard Oil. ${ }^{9}$ Second, phenomenal consciousness is necessary to welfare. If you aren't conscious, then you don't have welfare. This is true on several theories of welfare. The most well-known such theory is hedonism. Hedonism says that pleasures and pains are the only states that contribute to welfare. These are phenomenal states. Thus, only phenomenally conscious beings have welfare. But it's also true on other, more attractive, theories of welfare. For example, suppose one thinks that personal relationships, knowledge, and projects all enhance welfare, but only when you endorse having them. And suppose one thinks that endorsement is a phenomenal

\footnotetext{
${ }^{9}$ List (2016) defends this view.
} 
state. ${ }^{10}$ What it is to endorse a friendship is to feel positively toward it. On this view, perhaps you can have friendships you don't feel positively toward. But they only enhance your welfare when you do feel positively toward them. So, again, only phenomenally conscious things have welfare. We think some such theory is true. These further thoughts imply that organizations don't have welfare.

We finally come to the crucial point: human beings have interests which implicate group agents. Here we're taking our cues from an old master. As Aristotle knew, we have an interest in doing things and doing them well (see e.g., 1999, 1097b22-1098a20). People have an interest in running restaurants, building buildings, cultivating crops. And they have an interest in doings these things with aplomb. As Aristotle knew, too, we also have an interest in associating with others (see e.g., 2017, 1253a1-3; 1999, 1097b11, 1169b17). People have an interest in being with their friends, colleagues, even strangers. Aristotle didn't combine his two insights. ${ }^{11}$ But, very plausibly, we have an interest which combines the two. We have an interest in doing things well together with others. People don't just have an interest in running a good restaurant and another independent interest in being with their friends. They also have an interest in running a successful restaurant with their friends. This is an interest in playing a role in a specific type of collective enterprise: a group agent. We'll call it an 'interest in participation in successful group agency.' Such participation, we think, makes people's lives better.

Let's be clear about the nature of this interest. It is not just an interest in collaborating with others. It need not be satisfied by simply singing a duet with a friend. Rather, it is an interest in participation in group agency. Our claim that we have such an interest rests on three ideas. For a start, it rests on the idea that successful agency is valuable and especially impressive instances of such agency are especially valuable. Such impressive instances of successful agency are worth admiring: they are valuable in something like the sense that the Grand Canyon or the Mona Lisa are valuable. They are valuable in themselves. The second idea is that successful group agency is an especially impressive instance of such agency. Group agents can be extraordinarily complex and formidably capable. They can assimilate vast amounts of information, they can have extremely intricate intentional structures, and their actions are often on an awesome scale. Standard Oil, for example, refined 91 percent of the oil in the United States. Galveston Orphans Home looked after thousands of orphans over the course of a century. Both are extremely impressive instances of agency. The third idea is that we have an interest in participating in especially valuable things. We, for example, have an interest in participating in valuable projects or performances or practices. Participating in such things is good for us; it puts us in contact with something of value. From these three ideas it follows that participating in successful group agency is good for us: we have an interest in such participation. This interest is at the heart of the Group Interest View.

We want to clarify a few more issues about this interest. First, what is it to participate in group agency? It is for your actions to, in part, constitute the group's exercise of agency. This is done when your actions play a role in the group's decision-making: perhaps your vote in a committee determines what your restaurant group decides to do. And it is also done when your actions play a key role in the execution of those decisions: perhaps you are the chef who actually makes the restaurant's meals. In both cases, your actions constitute a group agent's exercise of agency. Second, when exactly is such participation good for you? We don't think every instance of participation in successful group agency is personally valuable. Imagine that you are forced into such participation. You might be an enslaved chef forced to labor reluctantly in the kitchen. Your cooking still helps constitute the restaurant's provision of meals. But this kind of participation does not seem good for you. The lesson here, we think, is that participation in group agency is only good for you when it is endorsed. You have to affirm your participation in group agency_to participate willingly_in order

\footnotetext{
${ }^{10}$ This is a twist on the view in Bykvist (2006).

${ }^{11}$ Although he came close. See e.g., Aristotle (2019, 488a7-14).
} 
for that participation to have value for you. Thus, those forced into such participation generally won't garner value from it.

Let us make one final clarificatory point. We think that people's interest in participation in successful group agency is the one most directly, deeply, and repeatedly impacted by how we act toward organizations. That is not to deny that other interests are impacted by such actions; of course they are. When a corrupt inspector closes down your restaurant, for example, that impairs the interests of the area gourmets. But it is to say that the group interest is almost always implicated and, often, very substantially so. It is this interest, we think, that explains the apparently fragmented moral status of organizations. So let's now apply this collection of claims-the Group Interest View-to the cases which make up our puzzle.

\section{4.b. Our cases reconsidered}

We start with political participation. Here we want to explain why we needn't give organizations the vote. The key point is that organizations don't themselves have an interest in getting the vote. This turns on the assumption we just made about welfare. Goldman Sachs has no welfare. So giving it the vote cannot promote its interests in the morally relevant sense; it doesn't have any such interests. Now, of course, it has "interests" in some sense. But this is the same sense in which plants have an interest in good lighting. It is not the sense that matters to moral claims. Thus, Goldman has no prima facie claim to voting rights. Now you, as an individual, may have an interest in your organization getting the vote. Perhaps you're an executive at Goldman. You think the laws treat banks harshly. You'd like your bank to get a vote on those laws. But this interest won't give you a claim that your group agent be given the vote. That's because we all have a strong interest in you not getting an extra vote for your organization. For suppose group agents did all get the vote. This would distort policymaking further in the direction of what such groups want. So your interest in your group getting the vote is outweighed by the rest of our interests in groups not getting the vote. Thus, we have no obligation to enfranchise Goldman Sachs.

Now let's turn to the right to life. Here we want to explain why we needn't treat organizations as if they had weighty rights to life. The key point is similar: organizations don't themselves have an interest in their own continuation. Again, that turns on our assumption about welfare. Standard Oil has no welfare, so it has no interest in its own continued existence. Compare that to John D. Rockefeller. He has welfare, so he has an interest in his continued existence. This is why Rockefeller has a right to life but Standard Oil does not. Now some people do have an interest in the continuation of Standard Oil. Perhaps Rockefeller had an interest in Standard Oil staying together. The corporation was his grand project. And everyone has an interest in the success of their projects. But other stakeholders have a weighty interest in breaking up Standard Oil. Its competitors have an interest in not being underhandedly forced out of business. Consumers have an interest in not paying over the odds for oil. These interests outweigh Rockefeller's interest in Standard Oil's continuation. They'd be less weighty than Rockefeller's interest in his own continued existence. That's why we can't break up John D. Rockefeller himself. But these other stakeholders' interests are weightier than his interest in the company's continued existence. So we are obliged to avoid ending Rockefeller's existence but not Standard Oil's.

Let's now turn to promise-breaking. Here we want to explain why we ought to keep the promises we make to organizations. The key point is that you can thwart others' interest in collective action by breaking your promises to their group agents. This is because we have an interest in taking part in instances of successful group agency. We have an interest in doing things well with others. But you tend to frustrate this interest when you break promises to a group agent of which we're a part. Agents, generally, can only act successfully when they can rely on their expectations. By making and breaking a promise to a group agent, you ensure that it can't rely on its expectations. This impairs its ability to act successfully. So you thwart individuals' interests in participation in successful group agency. Consider the University of Oxford. When you break your promise to the university, you 
impair its ability to act successfully. So you thwart the interests of its members in playing a role in successful group actions. Typically, this interest of the members outweighs your interest in making and breaking a promise to the organization. So when you promise something to an organization, you have an obligation to keep that promise. The interest the members of that organization have in it being able to rely on its expectations grounds this obligation.

Finally, we turn to gratitude. Here we want to explain why you seem to have debts of gratitude to organizations which have benefited you. Let's first consider the interests of members of such organizations. They have an interest in your helping out the organization. This is because that helping out usually helps them take part in a successful case of group agency. But consider your own interests. If you don't want to help out the organization, then you usually have an interest in not helping it out. Helping out is usually costly. If you don't want to incur that cost, then you have an interest in not helping out. When the organization has never benefited you, this offsets the interests of the members of that organization. Your interest in not donating to, for example, the DMV outweighs the interests of the DMV's employees in you donating. But we doubt that your interest offsets their interests when the organization has benefited you. This is because, in such cases, you should want to help out the organization. This makes your interest in not doing so illegitimate. But it is only legitimate interests which get placed on the scales of the interest theory of claims. Thus, in these cases, the interests of the members are not outweighed. They have a claim on you to help their organization do well.

The crucial premise here is that your interest in not helping out certain organizations is illegitimate. This premise relies on a principle about what you should want. The principle, roughly, says that when something valuable has played a valuable role in your life, you have weighty reason to want that thing to do well. ${ }^{12}$ One should understand that valuable role as nonaccidentally linked to the value of the thing itself. Consider the beauty of the Grand Canyon. Contemplating this beauty improves your life. But that improvement is not accidentally related to the Grand Canyon's value. The improvement is caused by, and a manifestation of, the Grand Canyon's beauty. Thus, when you've contemplated the Grand Canyon's beauty, you have weighty reason to want it to escape despoliation. This point extends to other cases. Suppose you've benefited from the tradition of Zen meditation, a profound novel, a hale horse. And suppose the benefit is nonaccidentally linked to what makes each thing valuable. Then you have reason to want them to flourish. You should want the great Zen tradition to escape commercialization, the novel bastardization, the horse the glue factory. Thus, to state the principle more precisely: when something's valuable properties nonaccidentally benefit you, this gives you weighty reason to want it to retain those properties.

We can apply this principle to organizations. When an organization's valuable properties nonaccidentally benefit you, you have weighty reason to want it to keep those properties. This is why your interest in not helping out certain organizations falls short of legitimacy. You only have that interest because you violate this independent constraint. You lack a desire to help them out that you ought to have. Let's see how this applies to Galveston Orphans Home. The members of the home have an interest in you giving it money. And the orphanage's value-the fact that it helps children-benefited you nonaccidentally. After all, the whole raison d'être of the orphanage is to help out orphans like you. So you should want to give the orphanage money; this will help preserve its good features. So your interest in not giving the orphanage money doesn't offset the members' interests in your doing so. Thus, the members of the orphanage have a claim on you that you help stop it going under. This is why it seems you owe things to the orphanage.

That completes our application of the Group Interest View to our cases. We now want to clarify two further things about our position. For a start, we're not saying that every obligation loosely

\footnotetext{
${ }^{12} \mathrm{Cf}$. "Participation in a valuable relationship is a source of relationship-dependent reasons" (Scheffler 2018, 5). Here, Scheffler is saying that being valuably involved with people gives you special reasons for action. Our claim is similar in spirit. We're saying that being valuably involved with things gives you special reasons for desire.
} 
connected with organizations should be explained via reference to the interest in participation in successful group agency. We think you can have more straightforward obligations to the members of groups. Consider gratitude: we think that, often, you will owe gratitude to those in an organization who have helped you. Sometimes, this debt of gratitude may outweigh any reason to help out the organization. If you have to choose between helping one of your flesh-and-blood benefactors and helping the organization, often you should help the former. But we deny that such individualistic duties exhaust your obligations around organizations. We defended that denial in section 2: some of your duties seem owed to the orphanage, rather than to any of its members. We think that, to explain these duties, one needs to invoke the interest in participation in successful group agency. ${ }^{13}$

Let's clarify a final point. We've shown how the Group Interest View can make sense of our seeming debts of gratitude and promissory obligations to organizations. But we seem to have duties of many other sorts to organizations. The Group Interest View illuminates these cases too. We'll just give three examples. First, consider organizational breakup. Although organizations lack a weighty right to life, it is wrong to break them up for little reason. We might permissibly break up Standard Oil, but we shouldn't break up Nike. Second, consider lying. It is wrong to lie to organizations. It would be wrong to mislead Nike about the size of the sneaker market in Suriname. Third, consider property. It is wrong to steal from organizations. Nike owns the shoes in its stores: you may only take them if it gives you permission to do so. So it would be wrong to shoplift from Nike. Each of these things can be explained by the Group Interest View. Breaking up an organization, lying to it, or stealing from it all impair its ability to act successfully. They all impair its agency. The members of the organization-the employees and shareholders-have an interest in participation in that agency. So these actions contravene the distinctively collective interests of each member. That is why they are wrong. Our general point here is that we seem to owe much more to organizations than just gratitude and the fulfillment of promises. A great virtue of the Group Interest View is that it can explain all these further apparent obligations too.

\section{4.c. Our worries overcome}

Let's turn to some worries about the Group Interest View. For a start, one might worry that it is too individualistic. After all, it emphasizes that the interest in participation in successful group agency is an interest of flesh-and-blood individuals. So one might worry that it will inherit the problems of Individualism: it will be unable to explain the transfer, discharge, and assumption of our obligations vis-à-vis organizations. So let us now show how the Group Interest View can explain these features of our obligations.

We begin with transference. The problem here was that organizations can change their members. But many of your obligations seem to stick with the organizations rather than the members. This is exactly what the Group Interest View predicts. Let's first see this with obligations of gratitude. Galveston Orphans Home benefited you. So you don't have a fully legitimate interest in not benefiting it. And the new social workers and administrators have an interest in you benefiting it. So you owe it to them to give back to the orphanage. Your obligation doesn't stick with the old employees. It remains stuck to Galveston Orphans Home. Now turn to promissory obligations.

\footnotetext{
${ }^{13}$ Let's consider one further idea to drive our point home. Some might think that, intuitively speaking, the reason you should give money to the orphanage is that you should "pay it forward." The idea is that, generally speaking, when you receive some benefit you have a duty to give others a like benefit in turn. You received a benefit from the orphanage-your good upbringingand so you should give other orphans a good upbringing. Perhaps such a duty to pay it forward does explain some of your obligations in the orphanage case. But it can't explain everything about them. The simplest thing it fails to capture is that, other things equal, you shouldn't discharge your duty by supporting any orphanage. You shouldn't give money to an orphanage in New York or Dallas, or one across the street from that which took you in. Other things equal, you should benefit the orphanage that raised you. Yet if your obligations all derived from a simple duty to pay forward your good fortune, there seems to be no reason why this would be the case. So this view doesn't fully capture our obligations around organizations.
} 
You've promised the University of Oxford to set up a graduate program. You'll thwart the university's agency by not lifting a finger. But the new members have a legitimate interest in the successful agency of Oxford. So they have a legitimate interest in your keeping your promise. Thus, you owe it to them to set up the graduate program. Your obligation does not stick with the old employees. It remains stuck to the university.

Second, consider the assumption of the claims corresponding to obligations. The problem here was that the members of organizations needn't assume claims of gratitude or promissory claims. They needn't incur any special sacrifice when benefiting you. They needn't take up your promise to the organization as if it was a promise to them. But you should pay your debts of gratitude and keep your promises all the same. The Group Interest View predicts this too. On this view, your obligations in these cases aren't really like comparable obligations to individual people. They have a different basis: they're grounded in the interest in participation in successful group agency. Thus, the members of the organizations needn't do what's needed to assume promissory claims or claims of gratitude. They need just assume the claims grounded in their interest in participating in group agency. And they assume these claims merely by willingly participating in the relevant group agent. So they do everything they need to assume the claims that the Group Interest View says that they have.

Finally, consider the discharge of your obligations toward organizations. One aspect of this problem was that it seems you have to fulfil your obligations as if you owed them to the organization. A second was that when you fail to fulfil them, you seem to have to compensate the organization itself. The Group Interest View gels with both. Let's start with the first aspect. The key point here is that the interests that ground your obligation are the interests of the members that you benefit their organization. They aren't interests that you benefit them. So donating money to the orphanage is a way of fulfilling the obligation grounded by these interests. But buying those individuals flowers isn't. Now turn to compensation. The key point here is that what makes for appropriate compensation depends on what interest you thwarted. The thwarted interest was in taking part in a particular instance of successful group agency. The best way to promote this interest will, usually, be to help out the agency of the relevant group agent. So this is what you should do. Take the promise to the university. You've impaired the agency of Oxford by breaking your promise. This impairs the interest of the university's members in participating in the university's agency. But those interests are not best made whole by giving each member a little money; they're best made whole by compensating the university itself. This will increase the university's ability to manage its own affairs-it will promote exactly the interest that you thwarted. So the most appropriate compensation goes to the university rather than to the members of the university. In sum, then, the Group Interest View is not too individualistic; it evades the problems of Individualism.

Yet one might have the opposite worry about our position. One might worry that the Group Interest View is too collectivistic. After all, it emphasizes an interest that essentially references a group. One might worry that, if we have such an interest, it will generate too many obligations vis-àvis groups. Let's consider a version of this worry that focuses on informal associations. The worry is that, intuitively speaking, there is a substantial asymmetry between our apparent obligations to such associations and those to a university or a business. Imagine, for example, that you are an anime fan. One might think that we cannot owe much at all to your fandom; it's too loose a collection of people to be even the apparent bearer of claims. Yet you and your fellow fans can do things well together: you can get together to celebrate Spirited Away with aplomb. So, on the face of it, the Group Interest View implies that there is no asymmetry between such informal associations and more structured organizations; we can have apparent duties to both. Thus the view might seem to clash with the intuitive distinctiveness of structured organizations. It might seem too collectivistic, in the sense that it over-generates apparent obligations to informal associations.

We want to make several points in reply to this worry. For a start, we don't think that, intuitively speaking, there is that deep an asymmetry between our obligations around the two kinds of groups. 
In particular, we do sometimes seem to owe things to informal associations. This comes out most clearly in the case of gratitude. It seems to us perfectly plausible that there is something like gratitude that one can owe to informal associations. You can feel grateful for the good times the fandom provided you, and this gratefulness can translate into a felt debt to the fandom. There isn't much difference between a fandom and an orphanage in this respect. Thus, it would not be problematic for a view to imply that one sometimes has apparent obligations to fandoms. Now, it is more plausible that there is a deep asymmetry between informal associations and formal organizations when it comes to promises: perhaps you should keep your promises to a university, but it is not clear whether you can be obligated to keep a promise to a fandom. Yet this specific asymmetry has a reasonably straightforward explanation. To accept a promise, one needs a certain level of cognitive sophistication. At the least, one needs to be able to understand that one is being made a promise and to rely on it in later deliberations. Fandoms don't have that level of sophistication. But a promise can only be made to something that can accept it. So we lack duties to keep promises to fandoms simply because we cannot make promises to fandoms. Intuitively speaking, then, the asymmetry between structured organizations and informal associations is usually shallow. And when it is deep, as in the case of promises, it can often be explained straightforwardly.

Yet, plausibly, there is some remaining intuitive difference between informal associations and structured organizations. Typically, when we seem to have duties to both, those to the former seem weightier. But this too is predicted by the Group Interest View. The key point is that the interest at the heart of this view is not simply that of collaborating with others. As we said in section 4.a, it is an interest in participation in group agency. Now one's anime fandom certainly involves some sort of collaboration. But one might doubt that the fandom is an agent at all. Thus, one might deny that participating in it helps in the slightest to satisfy the distinctive interest in participation in successful group agency. But even if one, more concessively, allows that such a fandom might be an agent, it is a simpler and far less impressive agent than is Standard Oil. It has far less intricate attitudes and can do much less than a structured organization precisely because of its relative informality. Qua agent, it is closer to a hummingbird than to a human being. Accordingly, participating in the fandom (and other informal associations) will not be as valuable as participating in more structured organizations. So our obligations surrounding structured organizations will be weightier than those around informal associations. That, we think, fully captures any real remaining asymmetry between the two groups. The Group Interest View is not, then, too collectivistic: it doesn't over-generate our obligations vis-à-vis groups.

In sum, we think the Group Interest View provides a good solution to our puzzle. Now, we haven't provided a full defense of this view. Most importantly, we haven't provided a defense of the interest theory of moral claims. And we don't intend to do so. This is a well-known theory with wellknown problems. ${ }^{14}$ The jury is still out on whether such problems can be solved-or swallowed. If they cannot, the Group Interest View will go down with the interest theory. But we wish to note that even if the interest theory is sunk, the spirit of the Group Interest View may be salvageable. That spirit is that important moral features of individuals implicate important features of collectives. This can be incorporated into other accounts of moral claims. Consider, for instance, theories which understand moral claims in terms of autonomy. On these theories, we have a claim that others don't, without good reason, infringe our autonomy. This gives us claims against promise-breaking, ingratitude, disenfranchisement, and termination. All infringe our autonomy without good reason. Now suppose we don't merely have an interest in participation in successful group agency. Suppose it infringes our autonomy when people hinder the functioning of a group agent in which we play a part. This would also explain the apparently fragmented moral status of organizations. Breaking promises to organizations and showing them ingratitude will hinder their members' participation in successful group agency, and so infringe their autonomy. When done without good reason, this

\footnotetext{
${ }^{14}$ See Sreenivasan $(2005,261-65)$ for some examples.
} 
will give those members a claim against such infringements. Now denying organizations the vote, or breaking up monopolists, will also infringe that autonomy. But there is good reason to do both. So these infringements will ground no claims. The Group Interest View is, we think, a better solution to our puzzle than this autonomy-based view. But the point is that the spirit of the view can survive the death of its letter.

\section{Political obligations}

We've presented an account of the moral patiency of organizations. On our view, they don't really have any moral status. But, often, the distinctively collective interests of individuals mean we must, in some respects, act as if they do. In this final section, we wish to explore the implications of this view for our political obligations. Or, to put it another way, we want to explore how our view impacts what we owe to the apex organization-the state.

Many theories of political obligations say that we owe things to the state. For example, consider the actual consent theory. On this view, we've actually promised to do as our political obligations oblige. For instance, we've promised to obey the law. On the main contemporary version of this theory, this promise is owed to the state (Beran 1987, 31). Yet, if the state cannot have promissory claims, then this theory cannot be right. The state is not the kind of thing to which one can owe the fulfilment of promises. Or consider gratitude theories. ${ }^{15}$ These theories point out that the state has done great good for us. It has educated us, protected us, clothed us, housed us. Our political obligations are just consequent debts of gratitude to the state. But, if we can't owe the state gratitude, then this theory also cannot be right. The state is not the kind of thing to which we can have such debts. Thus, the view we've presented imperils these theories of political obligations. Now, we don't claim it imperils every theory of political obligations. But it contradicts every theory which assumes that we can owe things to the state itself. And that makes up an important class of theories of political obligations.

But what the Group Interest View takes away with one hand it giveth with the other. It highlights a route out of the peril. In many states, ordinary citizens participate in state decision-making. They vote. They petition. They protest. This often affects what their state does. So it helps fulfil these citizens' interest in participation in group agency. ${ }^{16}$ And it helps fulfil that interest in a particularly spectacular way. State actions are awesome in both scope and aim. They're vaster in impact than most organizations' acts. And they do, or can, have distinctively political aims: to achieve a society in which all are truly free and equal. Thus, these ordinary citizens have a claim that you keep your promises to the state and pay it your debts of gratitude. This claim is grounded in their interest in participation in successful group agency. So promissory and gratitude theories of political obligations can and should be reconceived. They shouldn't hold that you owe your political obligations to the state. They should instead hold that you owe these obligations to the ordinary citizens of those states. The point generalizes to other theories of political obligations. Generally, these theories should not say that political obligations are owed to the state. They should say that they're owed to the members of that state in virtue of their participation in their state's agency.

But this is a route only some states can take. Only citizens in democratic states properly participate in their state's agency; those in autocratic states do not. To see this, note that there

\footnotetext{
${ }^{15}$ Plato discusses this theory in his Crito (2002, 48d-52d). Walker (1988) is its main modern advocate.

${ }^{16}$ On this view, the state's members include its citizens. Lawford-Smith $(2019,31-68)$ argues that such a state is only a group agent in a weak sense. We wish to make two brief points about this. First, her arguments mainly target the idea that the plurality of citizens are a group agent in any strong sense. We think that the plurality of citizens, together with the officials and the organizations that they're embedded within, are the relevant agent. We think many of her objections don't apply to this more inclusive, more structured, thing: it may be a group agent in a strong sense. Second, we think group agency in the weak sense is quite adequate for our purposes. We have interests in participation in these sort of group agents too, and that interest could explain our political obligations in a democracy.
} 
are two ways in which citizens can willingly participate in their state's successful agency. They can willingly participate in their state's decision-making or they can willingly participate in the execution of those decisions. Ordinary people in autocracies do not participate in their state's agency in the first way. They take no part in its decision-making. Now sometimes such citizens do help execute the state's decisions. During the Great Leap Forward, for example, the Chinese state decided to increase steel production. It mobilized Chinese citizens to melt down their pots and pans in backyard blast furnaces. These citizens were executing their state's decision. ${ }^{17}$ But we suspect that participation in such campaigns, and in the execution of autocratic decisions more generally, is very often unwilling. ${ }^{18}$ It is, we suspect, typically the fear of reprisals rather than genuine endorsement of the state's aims that induces such participation. So citizens in autocratic states don't typically participate in their state's agency in either of the ways they would have to to satisfy their interest in participating in successful group agency. So their participation won't ground a duty to keep one's promises or pay back one's debts of gratitude to an autocratic state.

Now, of course, some citizens of autocratic states do willingly participate in their state's agency. Many members of the ruling regime, for example, no doubt willingly participate in their state's decision-making. Some ordinary citizens of autocracies probably willingly participate in executing their state's decisions. But we think that these people's interest in participation in their state's agency is generally illegitimate. To see why, consider members of the ruling regime. They do have an interest in their state's successful agency. But the satisfaction of this interest violates other people's rights. This is simply because citizens in autocracies have a right to self-determination. The successful agency of the autocratic state is inconsistent with their self-determination. It substitutes their self-government with government by the ruling regime. So members of that regime might have an interest in your keeping your promises or repaying your debts of gratitude to their state. But the interest is illegitimate and, so, does not give you any obligations. A parallel point goes for people who willingly execute their autocratic state's decisions. Thus, the basis for political obligations that the Group Interest View highlights is not open to autocracies-it is open to democracies alone.

The substantive upshot of this is important and plausible: the subjects of autocracies are less likely to have political obligations than are the citizens of democracies. That the Group Interest View supports this conclusion, we think, redounds to its credit.

\section{Conclusion}

Let's end with the words of another. In July 1948, Hubert Humphrey said that the time had finally come for the Democratic party to "get out of the shadow of states' rights and to walk forthrightly into the bright sunshine of human rights." He went on to add that "[p] eople-human beings-this is the issue... ." We think that Humphrey's point was, in part, that it is wrong to think that states have rights. We have not put the point so beautifully, and our cause is nowhere near as noble. Yet we agree with Humphrey. We think that organizations generally don't have rights. They don't have any moral status whatsoever. But we have added a minor point of clarification. Although human beings are the issue, human beings do have distinctively collective interests. And these, often, give them claims that mimic those that organizations would have had they moral status. Now, this clarification does nothing to support the position against which Humphrey was remonstrating. But it does suffice, we think, to explain why, prima facie, organizations have a peculiar, fragmented moral status.

\footnotetext{
${ }^{17}$ For more on this episode, see MacFarquhar (1983, 113-16).

${ }^{18}$ For first-person accounts of mass mobilization campaigns in China, see Yiwu (2009). Such accounts ground our suspicion that endorsement of such campaigns was less than universal among ordinary citizens. Of course, ordinary citizens are often outwardly very enthusiastic about mass mobilization campaigns in autocratic states. But such outward expressions of enthusiasm are likely motivated by the desire to avoid punishment. For more discussion of this dynamic, see Marquez $(2017,131-35,147-52)$.
} 
Acknowledgements. For very helpful comments on earlier drafts of this paper, we thank Francis Cheneval, Alexander Dietz, Stefan Gosepath, Micha Gläser, Christoph Halbig, Alon Harel, Tyler John, Felix Koch, Michele Loi, Leonhard Menges, Nico Müller, Peter Schaber, Samuel Scheffler, three anonymous reviewers for the Canadian Journal of Philosophy, and audiences at the Zurich Colloquium in Political Philosophy, the FU/UZH Workshop on Practical Philosophy in Berlin, and the Constance/ Zurich Colloquium.

Adam Lovett is a doctoral candidate at New York University's Department of Philosophy. He has worked in political philosophy, ethics, and metaphysics. His current research focuses on how well real-world democracies live up to democratic ideals.

Stefan Riedener (DPhil, University of Oxford) is a senior assistant at the University of Zurich's Department of Philosophy. He has worked on normative uncertainty, moral emotions, and promises. His current research project is on the ethics of partiality.

\section{References}

Appiah, Kwame Anthony. 2011. “'Group Rights' and Racial Affirmative Action.” Journal of Ethics 15: 265-80.

Aristotle. 2017. Politics: A New Translation. Translated by C. D. C. Reeve. Indianapolis, IN: Hackett.

Aristotle. 2019. Generation of Animals \& History of Animals I \& Parts of Animals I. Translated by C. D. C. Reeve. Indianapolis, IN: Hackett.

Aristotle. 1999. Nicomachean Ethics. 2nd ed. Translated by Terence Irwin. Indianapolis, IN: Hackett.

Beran, Harry. 1987. The Consent Theory of Political Obligation. London: Croom Helm.

Briggs, Rachael. 2012. “The Normative Standing of Group Agents.” Episteme 9: 283-91.

Bykvist, Krister. 2006. "What Are Desires Good For? Towards a Coherent Endorsement Theory.” Ratio 19: 286-304.

Darwall, Stephen L. 2006. The Second-Person Standpoint: Morality, Respect, and Accountability. Cambridge, MA: Harvard University Press.

Epstein, Brian. 2015. The Ant Trap: Rebuilding the Foundations of the Social Sciences. New York: Oxford University Press.

Fine, Kit. 2012. “Guide to Ground.” In Metaphysical Grounding: Understanding the Structure of Reality, edited by Fabrice Correia and Benjamin Schnieder, 37-80. Cambridge: Cambridge University Press.

Hedahl, Marcus. 2017. "Collective Directionality: A New Possibility for Collectives as Objects of Normative Consideration." The Journal of Value Inquiry 51: 233-50.

Hess, Kendy M. 2013. "If You Tickle Us ...": How Corporations Can Be Moral Agents without Being Persons.” The Journal of Value Inquiry 47: 319-35.

Hess, Kendy M. 2014. "Because They Can: The Basis for the Moral Obligations of Certain Collectives." Midwest Studies in Philosophy 38: 203-21.

Heyd, David. 1982. Supererogation: Its Status in Ethical Theory. Cambridge: Cambridge University Press.

Huebner, Bryce. 2014. Macrocognition: A Theory of Distributed Minds and Collective Intentionality. New York: Oxford University Press.

Kramer, Matthew H. 2001. “Getting Rights Right.” In Rights, Wrongs and Responsibilities, edited by Matthew H. Kramer, 28-95. London: Palgrave Macmillan.

Lawford-Smith, Holly. 2019. Not in Their Name: Are Citizens Culpable for Their States' Actions? New York: Oxford University Press.

List, Christian. 2016. "What Is It Like to Be a Group Agent?” Noûs 52: 295-319.

List, Christian, and Philip Pettit. 2011. Group Agency: The Possibility, Design, and Status of Corporate Agents. Oxford: Oxford University Press.

MacCormick, Neil. 1977. "Rights in Legislation.” In Law, Morality and Society: Essays in Honour of H. L. A. Hart, edited by Joseph Raz and Peter M. S. Hacker, 189-209. Oxford: Oxford University Press.

MacFarquhar, Roderick. 1983. The Origins of the Cultural Revolution: The Great Leap Forward 1958-1960 Vol. II. New York: Columbia University Press.

Macnamara, Coleen. 2019. “Gratitude, Rights, and Benefit." In The Moral Psychology of Gratitude, edited by Robert Roberts and Daniel Telech, 96-117. London: Rowman \& Littlefield.

Marquez, Xavier. 2017. Non-Democratic Politics: Authoritarianism, Dictatorship and Democratization. London: Red Globe Press.

McConnell, Terrance C. 1993. Gratitude. Philadelphia: Temple University Press.

Owens, David. 2012. Shaping the Normative Landscape. Oxford: Oxford University Press.

Plato. 2002. Five Dialogues: Euthyphro, Apology, Crito, Meno, Phaedo. 2nd ed. Translated by George M. A. Grube. Indianapolis, IN: Hackett.

Raz, Joseph. 1984. “On the Nature of Rights.” Mind 93: 194-214.

Raz, Joseph. 1986. The Morality of Freedom. Oxford: Oxford University Press. 
Scheffler, Samuel. 2018. Membership and Political Obligation, Journal of Political Philosophy, 26: 3-23.

Simmons, A. John. 1979. Moral Principles and Political Obligations. Princeton, NJ: Princeton University Press.

Sreenivasan, Gopal. 2005. “A Hybrid Theory of Claim-Rights.” Oxford Journal of Legal Studies 25: 257-74.

Thomas, Natalie. 2016. Animal Ethics and the Autonomous Animal Self. London: Palgrave Macmillan.

Tollefsen, Deborah P. 2015. Groups as Agents. Cambridge: Polity.

Walker, A. D. M. 1980. "Gratefulness and Gratitude." Proceedings of the Aristotelian Society 81: 39-55.

Walker, A. D. M. 1988. "Political Obligation and the Argument from Gratitude." Philosophy \& Public Affairs 17: $191-211$.

Wallace, R. Jay. 2019. The Moral Nexus. Princeton, NJ: Princeton University Press.

Weiss, Roslyn. 1985. “The Moral and Social Dimensions of Gratitude.” Southern Journal of Philosophy 23: 491-501.

Wringe, Bill. 2014. "May I Treat a Collective as a Mere Means?” American Philosophical Quarterly 51: 273-84.

Yiwu, Liao. 2009. The Corpse Walker: Real Life Stories: China from the Bottom Up. New York: Anchor.

Cite this article: Lovett, A. and Riedener, S. 2021. Group Agents and Moral Status: What Can We Owe to Organizations? Canadian Journal of Philosophy 51: 221-238, doi:10.1017/can.2021.8 